\title{
How to transfer the conceptual structure of Old Babylonian Mathematics: solutions and inherent problems. With an Italian Parallel
}

Preliminary version!

Jens Høyrup

jensh@ruc.dk

http://www.akira.ruc.dk/ jensh

Beitrag zur Tagung

Zur Übersetzbarkeit von Wissenschaftssprachen des Altertums Johannes Gutenberg-Universität Mainz

27.-29 Juli 2009

Two introductory observations $\ldots \ldots \ldots \ldots \ldots \ldots \ldots \ldots \ldots \ldots \ldots$

The classical translations of Old Babylonian mathematical texts $\ldots \ldots \ldots$

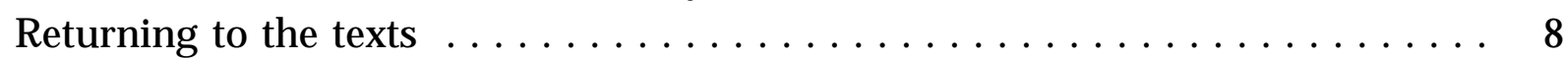

A list (12); The text groups (18); Text format (20)

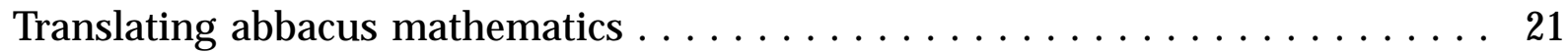

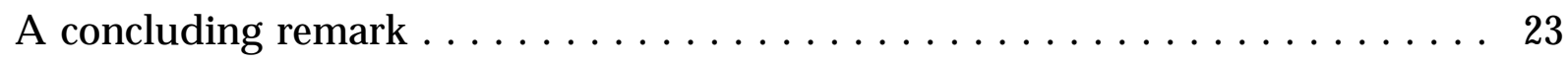

References ................................ 24

\section{Two introductory observations}

(1) At a random page in a book taken from one of my bookshelves one finds the following [Berry 1897: I, 321]:

\begin{tabular}{|c|c|}
\hline 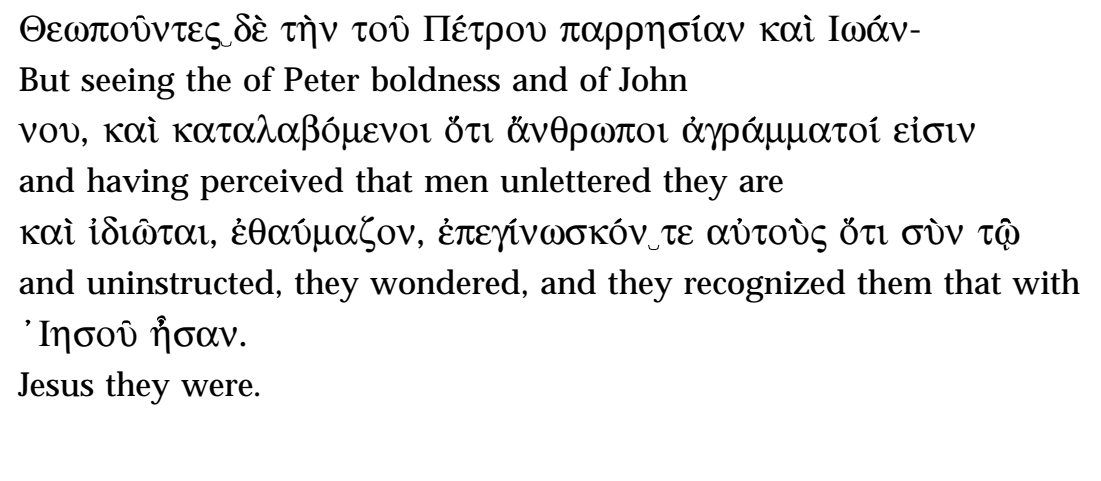 & $\begin{array}{l}\text { Now when they saw } \\
\text { the boldness of Peter } \\
\text { and John, and per- } \\
\text { ceived that they were } \\
\text { unlearned and ignor- } \\
\text { ant men, they marvel- } \\
\text { led; and they took } \\
\text { knowledge of them, } \\
\text { that they had been } \\
\text { with Jesus. }\end{array}$ \\
\hline
\end{tabular}

The passage is Acts 4:13. The Greek is of course the established text, the right margin presents the reader with the King James Version, and the interlinear English is, as can be seen, a very literal de verbo ad verbum translation. 
The introduction makes it clear whom the volume is meant to serve: not ordinary believers but the minister, the "Bible-preacher and Bible-teacher", who needs "some knowledge of Hebrew and Greek" so as to

- "understand the critical commentaries on the scriptures";

- "appreciate the critical discussions, now so frequent, relating to the books of the Old and New Testaments";

- "be certain, in a single instance, that in your sermon based on a scripture text, you are presenting the correct teaching of that text";

- "be an independent student, or a reliable interpreter of the word of God"

Obviously, the minister also needs to have a feeling of what this pedantic tool has to do with his creed and the creed of his flock; therefore the King James Version in the margin with its familiar pious reverberations.

In the present verse, there is only one (rather minor) substantial difference between the two translations; whether i $\delta \iota \omega \tau \eta \varsigma$ is to be translated "ignorant" (King James) or "uninstructed" (Berry). Both are possible according to the dictionary (e.g., Liddell \& Scott), the former choice corresponding certainly to the opinion the erudite King James translators would have about anybody uninstructed in classical languages, the latter to the vicinity to $\alpha \gamma \rho \alpha \mu \mu \alpha \tau o \varsigma$ (and to Peter's preceding sermon, hardly evidence of rhetorical or rabbinical training, nor however of generic "ignorance"). Elsewhere, and in particular if other translations for pious use are taken into account, more striking differences turn up ("young woman" versus "virgin", "brothers" versus "relatives").

(2) Let us then turn to the discussions among philosophers of science in the wake of Kuhn's Structure of Scientific Revolutions. Many early critics and many later superficial followers of Kuhn have taken the claim for incommensurability to imply that no communication and no rational argumentation is possible across a paradigmatic divide. This is evidently a wrong conclusion, built among other things on an absolutistic concept of rationality, and it was never intended by Kuhn. ${ }^{1}$ Breakdown of communication is partial, but communication is similar to the communication between different language communities with non-isomorphic conceptual structures [Kuhn 1970: 202-204], which can not be achieved by the de verbo ad verbum method. ${ }^{2}$ In this respect, the example

\footnotetext{
${ }^{1}$ See the postscript to the second edition of his Structure ... [Kuhn 1970: 198ff], which takes up the problem of incommensurability and the misunderstandings to which his original statements had led.

${ }^{2}$ I borrow an illustration from [Høyrup 2000: 305 n. 51], namely

the relation between the conceptual clusters "knowledge/cognition" and "Wissen/Erkenntnis/Erkenntnisvermögen." Cognition encompasses only little of what is covered by Erkenntnis and most (all?) of what is meant by Erkenntnisvermögen, and knowledge correspondingly more than Wissen. This is one among several linguistic reasons (non-linguistic reasons can be found) that epistemology looks differently in English and German; still, translations can be made that convey most of a German message to an English-speaking
} 
from the Acts is not representative.

\section{The classical translations of Old Babylonian mathematical texts}

"Higher" Babylonian mathematics (Old Babylonian as well as Seleucid ${ }^{3}$ ) was cracked in the late 1920s and the earlier 1930s, at a moment when Assyriology was about half its present age, almost two decades before the end of what Rykle Borger [2004: I, v] characterizes as the "düstere Handbuchlose Zeitalter der Assyriologie". The main locus of the process was Otto Neugebauer's newly founded Quellen und Studien zur Geschichte der Mathematik, Astronomie und Physik (Abteilung B: Studien, as well as Abteilung A: Quellen). It is true that François Thureau-Dangin, always interested in metrology and surveying calculation, had published the text AO 6484 already in [1922], but seeing only that it contained "arithmetical calculations". In [1928], Carl Frank had also published 6 mathematical texts from Strasburg, with transliteration and tentative partial explanations. Almost at the same time, however, H. S. Schuster, a participant in Neugebauer's seminar in Göttingen, discovered that certain problems in AO 6484 solved something like quadratic equations, ${ }^{4}$ and very soon Neugebauer was able to substantiate similar claims regarding the mathematical Strasburg texts, and to explore a number of other problem types.

Once the road had been opened, Thureau-Dangin was able to participate in the race (as he did in 1931-32), but on the whole without changing the approach. The programmatic declaration of Quellen und Studien ${ }^{5}$ should therefore tell us much about the perspective from which "Babylonian mathematics" was explored:

Durch den Titel "Quellen und Studien" wollen wir zum Ausdruck bringen, daß wir in der steten Bezugnahme auf die Originalquellen die notwendige Bedingung aller ernst

public.

However, such translations, in order to be adequate, may ask for the introduction of explained neologisms or for explanatory notes.

${ }^{3}$ The "Old Babylonian" period covers the period 2000-1600 ВСE (middle chronology); apart from an isolated text group from Ur (ed. [Friberg 2000], cf. [Høyrup 2002: 352-354] and below), which may date from the nineteenth century, the mathematical text belonging to this period belong to its second half (after 1800 BCE in the north-east, after c. 1750 in the south.

The Seleucid epoch coincides roughly with the third and second century BCE.

${ }^{4}$ That Schuster actually made the discovery I heard from Kurt Vogel in 1985. It is confirmed though less explicitly in a note added after proofreading to [Neugebauer 1929], according to which the Babylonian method for solving quadratic equations had now been discovered through analysis of AO 6484; that the essential step was due to Schuster; and that the whole analysis was to be published later in Quellen und Studien - as indeed it was, as [Schuster 1930].

${ }^{5}$ Signed by "Die Herausgeber", that is, Otto Neugebauer, Julius Stenzel and Otto Toeplitz. It seem a fair guess that Neugebauer is the main if not the sole author. 
zu nehmenden historischen Forschung erblicken. Es wird daher unser erstes Ziel sein, Qu ell en zu erschließen, d.h., sie nach Möglichkeit in einer Form darzubieten, die sowohl den Anforderungen der modernen Philologie genügen kann, als auch durch Übersetzung und Kommentar den Nichtphilologen in den Stand setzt, sich selbst in jedem Augenblick von dem Wortlaut des Originales zu überzeugen. Den berechtigten Ansprüchen b ei d e r Gruppen, Philologen und Mathematikern, nach wirklicher Sachkenntnis Genüge zu leisten, wird nur möglich sein, wenn es gelingt, eine enge Zusammenarbeit zwischen ihnen herzustellen. Diese anzubahnen soll eine der wichtigsten Aufgaben unseres Unternehmens sein.

The Quellen und Studien were to appear in two series:

Die eine, A, "Quellen", soll die eigentlichen Editionen größeren Umfanges umfassen, enthaltend den Text in der Sprache des Originales, philologischen Apparat und Kommentar und eine möglichst getreue Übersetzung, die auch dem nichtphilologen den Inhalt des Textes so bequem als irgend tunlich zugänglich macht. [...] Die Heften der Abteilung B, "Stu d i e n", sollen jeweils eine Reihe von Abhandlungen zusammenfassen, die in engerem oder weiterem Zusammenhang mit dem aus den Quellen gewonnenen Material stehen können.

Die "Quellen und Studien" sollen Beiträge zur Geschichte der Mathematik liefern. Sie wenden sich aber nicht ausschließlich an Spezialisten der Wissenschaftsgeschichte. Sie wollen zwar ihr Material in einer Form darbieten, die a u ch dem Spezialisten nützen kann. Sie wenden sich aber weiter an alle jene, die fühlen, daß Mathematik und mathematisches Denken nicht nur Sache einer Spezialwissenschaft, sondern aufs tiefste mit unserer Gesamtkultur und ihrer geschichtlichen Entwicklung verbunden sind, daß eine Brücke zwischen den sogenannten "Geisteswissenschaften" und den scheinbar so ahistorischen "exakten Wissenschaften" gefunden werden kann. [...].

Apart from the absence of "historians of mathematics" as a professional category, these ambitions could probably have been formulated today. However, if we concentrate on the Babylonian aspect, they were not easily filled out at the moment. In [1934: 204], Neugebauer still had to point out "daß wir über die ganze Stellung der babylonischen Mathematik im Rahmen der Gesamtkultur praktisch noch gar nichts wissen". (It was almost as true 40 years later.)

What little could be said about this matter had indeed been said by Schuster and Neugebauer already in 1929-30: that the text AO 6484 carries the name of a member of a well-known family of scholar-priests ${ }^{6}$, and that problems were constructed so as to give neat solutions [Neugebauer 1929: 73], with the implication that they were constructed and hence some kind of school problems. Instead of speaking of the capabilities of "Babylonian mathematicians" and thereby postulating the existence of such a category, Neugebauer also spoke consistently of what could be done by "Babylonian mathematics".

The school character of texts was a result of internal analysis, and everything else also had to be read from the texts themselves - no meta-information was available, that is, no texts speaking about mathematics and mathematical texts, as does for instance

\footnotetext{
${ }^{6}$ Schuster [1930: 194] cites Thureau-Dangin [1922: ]for this observation.
} 
the famous Egyptian "satirical letter" in Papyrus Anastasi I (known at the time in Alan Gardiner's edition [1911]).

Initially, extracting information from the texts was even harder than one imagines when reading such mature source editions as Mathematische Keilschrift-Texte (MKT) from 1935-1937 or Textes mathématiques babyloniens (TMB) from 1938. Cuneiform writing is indeed full of ambiguities, only resolved to some extent if one knows the period and genre of a text. Working up comprehension of a new genre is thus a highly circular hermeneutic process; it was even more so 80 years ago.

One example will suffice. The problems from AO 6484 analyzed by Schuster [1930] aim at the determination of two magnitudes, which Schuster following Thureau-Dangin

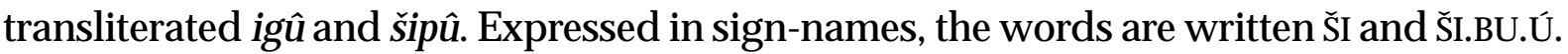
ŠI can also be IGI, which corresponds to the Akkadian reading igĥu. In an editorial note on p. 196 building on an observation made by A. Ungnad in 1917, Neugebauer pointed out that this term may stand in tables for the reciprocal of a number, but also according to an Assurbanipal text for "division". ${ }^{7}$ Not knowing that the genre of mathematical texts requires the former sense, he had to leave this question open. In the second term, all chose the reading ŠI.PU.Ú, corresponding to Akkadian šipû, and wisely abstained from translating (Neugebauer's note suggests a possible arithmetical meaning but characterizes it as "disputable").

When MKT and TMB were published, most difficulties of this kind had been pushed aside. For example, ŠI-PU-Ú had become igi-bu-ù. Neugebauer still upheld his "disputable" translation of the two terms ("Nenner" and "Zähler"), but only in the absence of more adequate words; he was fully aware and explained (MKT p. 349) that they constitute a pair of reciprocal numbers (as Schuster had already assumed though with less material on which to base the assumption). ${ }^{8}$

This derivation of the mathematical meaning of terms from the numbers found in the texts was almost the general rule. A few terms, it is true, were easily interpreted from their non-technical meaning - for example, wașābum ("hinzufügen, mehren" according to [Bezold 1926: 61], one of the dictionaries of the time) seemed likely to stand

\footnotetext{
${ }^{7}$ Actually, Ungnad's reading is mistaken, Assurbanipal boasts that he can find reciprocals. This, however, could only be seen with hindsight after the terminology had been fully deciphered in the 1930s. Assurbanipal boasts in parallel of mastering I.GI and A.RÁ; the latter being known to be a term for multiplication, it was a reasonable assumption that the former represented division, and that the accompanying verb patârum stood for the process of solving problems (but cf. below).

${ }^{8}$ Going one step further, Neugebauer and Sachs point out in MCT (p. 130) that the two terms are Akkadianized forms of Sumerian ig i and i g i. bi , "igi" and "its igi", following what ThureauDangin had done in TMB (pp. 14-16 and passim).

If we want to understand why Neugebauer could use these translations, we should think of the expression of the same number as numerator and denominator, $m /{ }_{1}=1 /{ }_{n}$. Then $m$ and $n$ form an igi-igi.bi couple.
} 
for an addition, while nasāhum ("ausreißen, entfernen, fortnehmen" according to [Bezold 1926: 200]) could hardly be anything but a subtraction. Most terms, however, did not appear from their non-mathematical interpretation to describe any mathematical operation - for example, elûm ("in die höhe kommen, hinaufkommen, hinaufziehen" according to [Bezold 1926: 29]) - or the cuneiform signs could not be interpreted as Sumerian or Akkadian words - for example, ZUR.ZUR (now read UL.UL and interpreted $\mathrm{d} \mathrm{u}_{7} \cdot \mathrm{d} \mathrm{u}_{7}$ ). Here, the only way was to observe what these operations did to the numbers surrounding them. Since "lifting up" 40 to 10 resulted in 400, while ZUR.ZUR transformed 10 into $100,{ }^{9}$ the former operation could be a multiplication, and the latter a squaring.

As illustrated by these two examples, a few identifications of mathematical operations had been made before the breakthrough of the outgoing 1920s (Frank did not introduce them). Most, however, were brought forth by Neugebauer and his collaborators and by Thureau-Dangin once he re-entered the undertaking.

The undertaking, we may say, was brought to a successful though preliminary end in 1937/38, when Neugebauer completed MKT and Thureau-Dangin brought out his own transcriptions and translations in TMB. ${ }^{10}$ The picture it produced now seems to be unduly modernizing. ${ }^{11}$ This character of the picture was not intended by Neugebauer and Thureau-Dangin. It came about for (at least) three reasons.

One is the use of modern numerical operations as a matrix for decipherment. In the first instance, at least, this could not escape an identification of the Babylonian operations with modern operations - thus to see, as mentioned above, elûm as

\footnotetext{
${ }^{9}$ Both examples are borrowed from [Frank 1928], who (not always correctly) transforms the sexagesimal into decimal place value numbers. Though this transformation is usually problematic when it comes to interpreting the mathematics of a text (and also contributed to preventing Frank from understanding much of his texts), it facilitates the present point.
}

${ }^{10} \mathrm{~A}$ "transcription" differs from a transliteration by interpreting logograms as phonetically written Akkadian, thus already containing a second level of interpretation (where transliteration can be considered the first and the translation a third level). While acknowledging that this involved loss of information Thureau-Dangin chose the transcription because the volume contained nothing not already published in philologically adequate form, and because his aim was to "mettre des documents à la disposition des historiens de la pensée mathématique" (TMB, p. xl) in an affordable volume.

Wolfram von Soden [1939:144], from whom the latter information is taken, rightly points out that the great philologist of course could not abstain from including many observations and much material which were rather aimed at Assyriologists.

${ }^{11}$ I prefer to avoid the epithet "anachronistic", which has developed into a mantra - an element of ritual deprived of the meaning it may once have possessed. Cf. the parodic use of the term in [Hon \& Goldstein 2008] and Hardy Grant's review of that book [2009].

It is easy, under the pretext of avoiding anachronisms, to eliminate descriptions that use modern categories; but if we do not then describe it in terms that are not ours - which is recommendable but much more difficult, and rarely done by those who excel in using the mantra - we end up having no way to speak of the historical material. 
multiplication and ZUR.ZUR as numerical squaring. Further, the same matrix influenced the translations in so far as it was attempted to make translations that were "substantially", ${ }^{12}$ not etymologically adequate.

It should be observed that neither Neugebauer nor Thureau-Dangin took systematic advantage of these identifications with modern operation in their translations, translating terms which appeared to mean the same with the same term, although exactly this might seem "substantially adequate". ${ }^{13}$ They both often (not always) tried to translate different Akkadian words differently (but not to distinguish logograms from syllabic writings when they felt sure they were equivalent). Even though they never explain it they must also have been aware that terms that seem to be mathematical synonyms cannot have been fully synonymous for the Babylonians - when repairing a broken passage none of them ever chooses what can now be seen to be the wrong operation, and once Neugebauer (justly) chides the compiler of a text for choosing a wrong multiplication (MKT I, p. 180).

The next reason things came to look modern was the application of the more general matrix of available types of mathematics - roughly spoken, numerical and Euclideangeometric (both with or without explicit proof). In some way (but under the general "numerical" heading) we may also count equation algebra, either in symbolic form or the rhetorical algebra of al-Khwārizmī. The latter was referred to explicitly by Thureau-Dangin [1940: 300f], the former by Neugebauer (but only in the sense that he claimed numerical steps to be the same - e.g., [Neugebauer 1932: 12]).

The effect of this second matrix can be seen in the discussions of both protagonists of the problem AO 8862 no. 1, in which the difference between the length and the width of a rectangle is added to its area. From this addition both conclude [Neugebauer 1932: 12; Thureau-Dangin 1940: 302] that the geometric terminology of problems dealing with square and rectangular sides and areas is purely formal, and that the thinking is numerical - tertium non datur within this matrix.

The third reason for the emergence of the modernizing interpretation must be

12 "Sachlich" - MKT III, p. 5 n. 20. The words are found within a polemic with Thureau-Dangin, but it characterizes the approach of both.

${ }^{13}$ Neugebauer (MKT I, p. viii) is emphatic on this account: "Die Übersetzung ist selbstverständlich im Prinzip eine wörtliche". But apart from apologizing for the inconsistencies which are inescapable in a similar undertaking (and not only, as Neugebauer modestly claims, because of the imperfections caused by the long duration of the work), he points out that

der Sinn der Übersetzung nur darin gesehen werden kann, den sachlichen Inhalt eines Textes in Großen und Ganzen richtig wiederzugeben, daß sie aber keineswegs als Grundlage für Fragen der Terminologiegeschichte dienen kann und soll. Die Bedeutungsgeschichte der Termini zu untersuchen ist noch ein Programm; es zu erleichtern habe ich in Teil II, § 3 ein ausführliches Glossar angelegt. Die Übersetzung soll aber nur ein allgemeiner Wegweiser sein, selbstverständlich genau genug, um den Inhalt korrekt erfassen zu können, nicht aber, um Feinheiten der Terminologie und Grammatik daran ablesen zu können. 
imputed to the users. Careful formulation is no guarantee of careful reading, and most users were not really interested "in der Betrachtung des ges ch ich tlich en Werden mathematischen Denkens", as Neugebauer had written in 1929, but in finding what they knew as mathematics - less fully developed, of course, but none the less the same kind - in the historical record. For this purpose they were in no need to read (and hardly cared to read) the translations and the appurtenant explanations. The formulae explaining why the Babylonian calculations were right (understood as "what they were really about") sufficed. In our initial simile, these readers felt so well in the pious atmosphere provided by the King James (here, the formulae explaining everything in familiar idiom) that they saw no reason to read the small interlinear print (i.e., the careful verbal translations) - Neugebauer's warning (MKT I, viiif) notwithstanding that

Der Kommentar bildet eine notwendige Ergänzung der Übersetzung und ist stets zu ihrer Begründung und Verwertung heranzuziehen. Um den Umfang des ganzen nicht zu schwer anschwellen zu lassen, habe ich mich in den Kommentaren oft ziemlich kurz gefaßt. Dem Benutzer, der wirklich über diese Texte urteilen will, kann doch nicht erspart werden, sich mit allen Einzelheiten genau vertraut $\mathrm{zu}$ machen [...].

\section{Returning to the texts}

This classical interpretation, mostly in the superficial second-hand reading, became the orthodoxy for half a century or so. The situation is well illustrated by a 75 pages' paper [Goetsch 1968] in Archive for History of Exact Sciences rehearsing "die Algebra der Babylonier". It quotes some three terms in the original language, lists a few metrological units, and is somewhat more generous when it comes to quotations from Neugebauer's translations. ${ }^{14}$ On the whole, however, everything is explained in modern equations and in a commentary supposing this to be what "Babylonian algebra" is. It also treats Old Babylonian and Seleucid mathematics as indistinguishable - whereas both Neugebauer and Thureau-Dangin had been fully aware of the differences. ${ }^{15}$ Whereas Neugebauer's and Thureau-Dangin's editions of the texts can, grosso modo,

\footnotetext{
${ }^{14}$ However, not always in a way that demonstrates understanding. On p. 83, a problem supposedly dealing with Nenner and Zähler is quoted - but without Neugebauer's explanation that these names are used in the absence of better alternatives and stand for a pair of reciprocals (cf. above, text before note 8) - probably because Neugebauer's explanation is linked to a different problem.

${ }^{15}$ Thus Neugebauer [1932: 5f, emphasis added],

der ganze Charakter der "babylonischen" Mathematik von Hammurapi bis gegen die Perserzeit [ist] allen Anschein nach ein derartig stationärer, daß das Datierungsproblem für alle geschichtlichen Fragen (wenigstens heute noch) nur eine sekundäre Rolle spielt,

and Thureau-Dangin [1940: 311]

ce texte très tardif [BM 34568, a Seleucid text] ne peut être considéré comme un témoin de l'authentique tradition babylonienne.
} 
be compared to the Greek and interlinear texts of the initial quotation from Acts 4, Goetsch's presentation corresponds to the King James version, not exactly wrong but so neatly enshrouded in the familiar style of mathematics that any challenge to conventional institutional piety and habits is avoided.

A few decent exceptions can be mentioned - thus Kurt Vogel [1959], A. A. Vajman [1961] and B. L. van der Waerden [1956]. The former two indeed understood the original language, and van der Waerden at least read the translations with care. Their level of modernizations was thus, we may say, comparable to that of Neugebauer and ThureauDangin. So was on the whole that of Neugebauer's and Sachs' Mathematical Cuneiform Texts [MCT] from 1945 (even though this volume is less cautious in its use of the categories of modern mathematics than MKT). As far as I am aware, the sole Assyriologist who expressed misgivings about the reading of the Babylonian texts as consisting of almost-modern equations was von Soden; ${ }^{16}$ none the less, the analysis [Gundlach \& von Soden 1963] of "Einige altbabylonische Texte zur Lösung »quadratischer Gleichungen «" made full use of algebraic equations - there was no other way at the time.

In 1982, as several participants in our meeting will know, I was provoked to return to the original texts after having relied for discussions of the social embedding of Mesopotamian mathematics on the classical translations and basically believing in Thureau-Dangin's reading as "rhetorical" algebra. Already when I looked more closely at the translations they made me suspect that the apparent "mathematical synonyms" in the Old Babylonian texts (these - and indeed solely those of them that contain words - are the only ones I shall discuss in this section) were not seen as synonymous at all by the authors of the texts (an homage to the translators!), and as soon as I got hold of a dictionary and a grammar it became obvious. It turned out, for instance, that one of two "additions" could not be used for a "quadratic completion", and the other not for the addition of different dimensions (lengths and areas, areas and volumes, men and bricks, etc.). ${ }^{17}$ Even though the two terms had seemed to be "mathematical synonyms", they cannot have been so within the mathematical practice of the calculators who employed them.

All in all, there turned out to be two different "additions", two different "subtrac-

\footnotetext{
${ }^{16}$ Namely in [von Soden 1974: 28]:

Die Mathematikhistoriker setzen die babylonischen Ausrechnungen m. E. vorschnell in uns gewohnte Gleichungen, noch dazu oft mit allgemeinen Zahlen, um und werden dadurch der Andersartigkeit des mathematischen Denkens im alten Orient nur unzureichend gerecht.

${ }^{17}$ Fortunately, I did not discover the two or three exceptions to the latter rule before I had a framework within which they were explainable (cf. note 20). The former rule has no exceptions.

Those who do not know what a "quadratic completion" is should not worry; for the present argument it is only of importance that it is a particular, easily recognizable operation (essential for the solution of quadratic problems).
} 
tions", two different "halves", and no less than four operations that had been conflated as "multiplication". ${ }^{18}$ Beyond their syllabic Akkadian writing, almost all of them could be written by a standard logogram. Several operations could also be referred to by two or more terms which must have been "mathematical synonyms" to the Babylonian calculators, in the sense that in the same mathematical situation one text may employ one of the terms and another text another one.

All of this was at odds with the traditional numerical interpretation - within which "there is only one multiplication", as Thureau-Dangin observes somewhere. Everything turns out to fit instead an interpretation where the sides and areas of square and rectangular figures spoken of in the "algebra" texts are really measurable sides and areas of geometric squares and rectangles - but within a geometry which distinguishes only "right" from "wrong" angles; in which the general angle has thus no place as a quantifiable magnitude; in which similarity is a primary and not a derived concept; ${ }^{19}$ and in which lines may be provided with an implicit width of 1 linear unit, for which reason they may be added to or subtracted from areas. ${ }^{20} \mathrm{~A}$ representation of geometry, finally, where measuring numbers are used as identifiers for entities (which are thus really "magnitudes" in a much more direct sense than we are accustomed to). ${ }^{21}$

This "geometric" interpretation (as I shall call it, hoping that its being different from our abstract, angle-based geometry in a Euclidean plane be not forgotten) also makes sense of several features of the texts which Neugebauer and Thureau-Dangin had to bypass in silence - addition and subtraction, not simply to respectively from a number but from "the bowels of" a number/magnitude; "carrying" of a number/ magnitude to another number/magnitude before it is subtracted from it; etc. Finally, it gives new clues to the procedures used in a number of properly geometric texts.

In principle, all of this can of course be discussed with reference to the transliterated text. In practice, an attempt to do so would exclude all readers who do not already

\footnotetext{
${ }^{18}$ This, and most of what follows in this section of the paper, can be drawn from [Høyrup 2002].

${ }^{19}$ As is the Greek concept of similar figures as figures where angles are the same and corresponding linear distances are proportional - at least if we identify definition and concept, which is of course a dubious though oft-made step.

${ }^{20}$ For this concept of "broad lines" and their wide diffusion in pre-Modern mensuration, see [Høyrup 1995]. As far as addition is concerned, the distinction between the two additive operations and the trick of supplying lines explicitly with a width 1 (designated in various ways, showing this to be a secondary development), the Babylonian calculators managed to eliminate the "large lines", which even they must hence have found problematic; but in subtraction they never did anything similar.

${ }^{21}$ One may see this sketchy characterization of Old Babylonian "geometry" as an attempt to speak of the historical material "in terms that are not ours", as formulated in note 11 - of course ultimately based on our terms (we have no others) but not identifying the historical category with a single one of ours.
} 
know at least basic Akkadian. Moreover, an understanding of the transliterated texts based directly on standard dictionaries which themselves presuppose the modernizing interpretation established in the 1930s (as, with due respect, must be said about von Soden's Akkadisches Handwörterbuch as well as the Chicago Assyrian Dictionary when they come to determining the meaning of terms within mathematical texts) cannot avoid being caught in the spell of modernization. Regardless of Neugebauer's warning about the role of a translation (which of course remains valid, but whose limit between what the translation can do and what it cannot do is pushed forward), a translation system has to be devised which reflects as many of the textual details and structures as possible.

The first request is of course that the same term shall always be translated by the same term, and no two different terms (securely established logographic/syllabic equivalents excluded) by the same term.

This leaves the question of the actual translation terms unsolved. As we know, however, nobody has ever tried to write a real geometry about the Hilbertian ingredients of a Bierstube. Even in the era of formalism, it was always clear that a terminology whose general semantics clashes with the properties of objects blocks mathematical thinking and creativity. Babylonian terminologies, even if technical (which remains to be ascertained), were based on the words of non-technical language, and ultimately derived from their meaning (or one of their meanings) within this general usage perhaps as metaphors, perhaps directly because the normal meaning could fit the technical context. Translations must therefore be chosen so as to correspond to the meanings of Babylonian terms in general usage. ${ }^{22}$ To a limited extent, and in cases where it is certain that terms were really technical, they may be borrowed as loanwords; most obviously this can be done for words which were already Sumerian loanwords in Akkadian (igi and igi.g u b are the most obvious candidates - cf. below, note 38 and appurtenant text).

It could be objected that correspondence to general usage implies that one translates technical terms as is they were not technical. Doesn't Neugebauer's charming translation of " $\sin ^{2} \alpha+\cos ^{2} \beta=1$ " into "viereckiger Busen von $\alpha$ vermehrt um den viereckigen

\footnotetext{
${ }^{22}$ This principle may conflict with the principle of translating logograms in the same way as syllabically written equivalents. One example is the couple nasăhum/zi . The former word means "to tear out"; the latter is likely to be a shortened writing for zi.zi, mar $\hat{u}$-stem of zi, known as a term for subtraction from a Sumerian text from the 21st century (Šulgi-Hymn B, ed. [Castellino 1972: 32]) and probably to be understood as "take up from" (namely, from the counting board). Since the term was used in Old Babylonian times within texts which were supposed to be pronounced in Akkadian, it seems safe to assume that the original meaning of the Sumerian term had disappeared from the semantics of the logogram, and that it is thus to be translated in the same way as nasăhum.

However, it must be decided from case to case whether a logogram is really meant to be the equivalent of an Akkadian term. Equivalence in one text or function does not necessarily entail equivalence in other texts or functions.
} 
Mitbusen von $\alpha$ ist gleich eins" apply here? ${ }^{23}$ The answer is that technical meanings should not be imported from later mathematics - they have to be discovered through work on the texts themselves - if not through "immersion", in the idiom of language training, then through analysis of the text corpus at large.

The effort to keep close to general usage does not eliminate further choice. One of the themes that always interested the historiography of Mesopotamian mathematics was the question of historical development and legacy - within the Mesopotamian world, and from Mesopotamia to surrounding and later cultures. The choice of translations may mask possible connections - but a translation may also beg the question and suggest links that are not well-established. Here care must be taken, and translations should not be chosen that suggest more than warranted.

\section{A list}

Without trying to be exhaustive, I shall list a number of terms and operations with my standard translations and with commentaries:

Additive operations:

\begin{tabular}{|c|c|c|}
\hline wașābum/d a h & to append ${ }^{24}$ & $\begin{array}{l}\text { a concrete, asymmetric operation; if } a \text { is appended to } B, B \\
\text { conserves its identity but changes its magnitude }\end{array}$ \\
\hline $\begin{array}{l}\text { kamārum/ } \\
\text { ğa r.g̃a r /UL.GAR }\end{array}$ & to heap ${ }^{26}$ & $\begin{array}{l}\text { a symmetric additive operation, which may concern the } \\
\text { measures of entities (thus allowing addition irrespective of } \\
\text { dimension) }\end{array}$ \\
\hline $\begin{array}{l}\text { kimirtum/ } \\
\text { ga r. ga r /UL.GAR }\end{array}$ & the heap ${ }^{27}$ & the sum by heaping \\
\hline kimrātum & the heaped ${ }^{28}$ & $\begin{array}{l}\text { plural of kimirtum; the sum by heaping, but still thought } \\
\text { of as the collection of constituents }\end{array}$ \\
\hline
\end{tabular}

Subtractive and dissolving operations:

\begin{tabular}{|c|c|c|}
\hline nasāhhum/zi & to tear out & $\begin{array}{l}\text { an identity-conserving concrete removal, inverse opera- } \\
\text { tion of "appending" (cf. note } 22 \text { ) }\end{array}$ \\
\hline
\end{tabular}

\footnotetext{
${ }^{23}$ MKT I, p. viii. Neugebauer's jibe, we should note, was directed at a different target - namely the expansion of compact ungrammatical logographic writing into grammatical syllabic Akkadian.

${ }^{24}$ My reason for not choosing "to join (to)" is that I have reserved this translation for the term tepûm, which is employed in Late Babylonian texts with the same function.

${ }^{25}$ In consequence, the sum by this operation has no specific name.

${ }^{26}$ On earlier occasions, I have used "to accumulate".

${ }^{27}$ Or "the accumulation".

${ }^{28}$ Or "the accumulated".
} 


\begin{tabular}{|c|c|c|}
\hline harasum & to cut off & $\begin{array}{l}\text { another concrete removal, preferred in a few texts (while } \\
\text { certain others have a tendency to "cut off" from lines } \\
\text { and "tear out" from areas) }\end{array}$ \\
\hline tabālum & to withdraw & $\begin{array}{l}\text { another concrete removal, used occasionally about what } \\
\text { can "justly" be removed }\end{array}$ \\
\hline šutbum & to make go away & $\begin{array}{l}\text { sometimes used within arguments of "false position" } \\
\text { about the removal of the "due" fraction }\end{array}$ \\
\hline $\begin{array}{l}\text { A eli } B d \text { itter } / A \\
\text { ugu } B d \text { dirig }\end{array}$ & $\begin{array}{l}A \text { over } B, d \text { it goes } \\
\text { beyond }\end{array}$ & $\begin{array}{l}\text { comparison of two different concrete magnitudes, neces- } \\
\text { sarily of the same kind }\end{array}$ \\
\hline dirig & the going-beyond & excess by previous operation \\
\hline $\begin{array}{l}\text { A ana } B \text { d imtil } \\
\text { la } 1\end{array}$ & $\begin{array}{l}A \text { to } B, d \text { it be- } \\
\text { comes smaller }\end{array}$ & $\begin{array}{l}\text { "comparison the other way round", used when the text } \\
\text { format or other considerations require it }\end{array}$ \\
\hline bêrum & to single out & $\begin{array}{l}\text { rarely occurring inverse operation of heaping, separating } \\
\text { the sum into constituents }\end{array}$ \\
\hline
\end{tabular}

\section{"Multiplications"}

\begin{tabular}{||l|l|l||}
\hline a.rá & steps of & $\begin{array}{l}\text { the term used in the tables of multiplications, that is, for } \\
\text { the multiplication of number by number }\end{array}$ \\
\hline našûm/íl & to raise & $\begin{array}{l}\text { a concrete multiplication, involving a sometimes hidden } \\
\text { consideration of proportionality; originally from volume } \\
\text { computation, "raising" the base from its standard thick- } \\
\text { ness 1 (k ù š to the real height; also used for the deter- } \\
\text { mination of areas and in multiplication by a reciprocal }\end{array}$ \\
\hline$($ elûm)/nim & to lift" & $\begin{array}{l}\text { a mathematical synonym of the preceding; mostly writ- } \\
\text { ten with the logogram }\end{array}$ \\
\hline $\begin{array}{l}\text { (ana } n) \text { eșepum/ } \\
\mathrm{tab}\end{array}$ & $\begin{array}{l}\text { to repeat (until } \\
n)^{30}\end{array}$ & $\begin{array}{l}\text { no genuine multiplication but a concrete repetition } \\
(2 \leq n \leq 9), \text { transforming for instance a triangle into a rec- } \\
\text { tangle }\end{array}$ \\
\hline
\end{tabular}

\footnotetext{
${ }^{29}$ In non-technical contexts, "to be/become/make high" would be a better translation. In its mathematical function, where it is linked to a preposition ana/ "to", this would be too clumsy.

${ }^{30}$ The general meaning is "to be/make double, to clasp to, to duplicate". The coupling to "until $n$ " makes a translation "to double" awkward.
} 


\begin{tabular}{|c|c|c|}
\hline $\begin{array}{l}\text { šutakūlum/ } \\
\text { ì. } g \mathbf{u}_{7} \cdot g \mathbf{u}_{7}\end{array}$ & $\begin{array}{l}\text { to make }(a \text { and } b \\
\text { resp. } c) \text { hold }^{31}\end{array}$ & $\begin{array}{l}\text { no multiplication at all but a construction of a rectangle } \\
\text { with sides } a \text { and } b \text { respectively of a square with side } c \text {; } \\
\text { often implies a tacit determination of the area }\end{array}$ \\
\hline takillum & the made-hold & the side which has been caused to hold a square ${ }^{32}$ \\
\hline $\begin{array}{l}\mathrm{d} \mathrm{u}_{7} \cdot \mathrm{d} \mathrm{u}_{7} / \text { UR.UR/ } \\
\text { NIGIN }\end{array}$ & to make hold & $\begin{array}{l}\text { alternative logograms for šutakūlum; the first may actual- } \\
\text { ly stand for nitkupum, "to make butt each other", the } \\
\text { third (two squares glued together) may be iconic rather } \\
\text { than linguistic. }\end{array}$ \\
\hline šutamhurum & $\begin{array}{l}\text { to make }(a) \text { con- } \\
\text { front }\end{array}$ & to make $a$ confront itself as the side of a square \\
\hline $\begin{array}{l}\text { mithartum/ } \\
\text { íb. } \mathrm{si}_{8}{ }^{34}\end{array}$ & the confrontation & $\begin{array}{l}\text { the square configuration understood as the frame, para- } \\
\text { metrized by the side (that which confronts its equal) }\end{array}$ \\
\hline LAGAB/NIGIN & & $\begin{array}{l}\text { probably iconic logograms for both šutamhurum and } \\
\text { mithartum (the former is a single square, the latter a } \\
\text { doubled square) }\end{array}$ \\
\hline Q.e $s$ íb.si ${ }_{8}$ & by $Q, s$ is equal & $\begin{array}{l}\text { this Sumerian phrase means that "close by" (.e) the } \\
\text { surface } Q \text { laid out as a square, } s \text { is the side. There is } \\
\text { evidence that the scribes of the } 18 \text { th c. reinterpreted the } \\
\text { terminative-locative suffix .e as an ergative suffix (the } \\
\text { two coincide). }{ }^{37} \text { English "by" renders this ambiguity } \\
\text { perfectly }\end{array}$ \\
\hline
\end{tabular}

${ }^{31}$ The logogram ì. $\mathrm{g} \mathrm{u}_{7} \cdot \mathrm{g} \mathrm{u}_{7}$ should actually stand for the near-homophone šutākulum, "to make eat together/eat each other"; this use of the "rebus principle" had been fundamental to the whole development of cuneiform phonetic writing and therefore should not astonish us.

A more complete translation of šutakulum (which is a causative-reflexive form) would be "to make hold each other/hold together" - and since the double object may be connected by itti, "together with", "together" is to be preferred. Since it is anyhow obvious that the two sides of a rectangle need to act together when holding it, I omit "together".

It would be tempting to translate "let $a$ and $b$ contain [a rectangle]". But this would suggest (via the established English translation of Euclid's Greek!) that the Babylonian and the Greek expression were linked historically, for which we have no evidence at all.

${ }^{32}$ Occasionally also a number which the calculator has been told to let his head hold, cf. below.

${ }^{33}$ Since it could also be a logogram for lawûm or one of its derived forms ("to surround" or perhaps "to make surround"), the iconic reading is not quite certain.

${ }^{34}$ This logographic writing is found in the so-called "series texts" but is otherwise very rare; cf. below on the normal use of $1 \mathrm{~b} . \mathrm{si}_{8}$.

${ }^{35}$ Numerically, the mithartum thus is the length of a side and has an area - while our square configuration, understood primary as a Euclidean "figure", i.e., as that which is contained by a boundary, is its area and has a side. The two concepts are different, but none is more paradoxical than the other.

${ }^{36}$ However, cf. note 33 (and observe that even LAGAB may be a logogram for lawûm).

${ }^{37} 19$ th-c. texts from Ur show that this is indeed a reinterpretation and not what was originally intended, cf. [Høyrup 2002: 26 n. 42]. 


\begin{tabular}{||l|l|l||}
\hline íb.si fas noun) $_{8}$ & the equal & $\begin{array}{l}\text { some texts do not use the Sumerian term as a verb but as } \\
\text { a noun (at times as ba.si } \mathrm{i}_{8}, \text { or Akkadianized as basûm). } \\
\text { It may be the side of the square, but also of a cube (or } \\
\text { further generalized) }\end{array}$ \\
\hline $\begin{array}{l}\text { mehrum/ } \\
\mathrm{gaba}(. \mathrm{ri})\end{array}$ & the counterpart & $\begin{array}{l}\text { the counterpart of "the equal" of a square configuration, } \\
\text { meeting it in a corner. Outside mathematics it may inter } \\
\text { alia designate the duplicate of a tablet }\end{array}$ \\
\hline
\end{tabular}

Reciprocals, division and bisection

\begin{tabular}{|c|c|c|}
\hline $\begin{array}{l}\operatorname{igi} n \\
(\tilde{g} \operatorname{c} a ́ l(. b i))\end{array}$ & igi $n$ & $\begin{array}{l}\text { designates the reciprocal of } n \text {, but mainly (not always) as } \\
\text { appearing in the table of reciprocals, not abstractly - } \\
\text { whence the use of a loan-word }{ }^{38}\end{array}$ \\
\hline $\begin{array}{l}\text { igi } n \text { patārum/ } \\
\mathrm{d} \mathrm{u}_{8}\end{array}$ & to detach ig i $n$ & $\begin{array}{l}\text { finding the reciprocal of a number, probably imagined as } \\
\text { the detachment of one part from a bundle consisting of } n \\
\text { parts }^{39}\end{array}$ \\
\hline igi $n$ (g̃ál) & $n$th part & $\begin{array}{l}\text { the same expression may also be used to designate the } \\
n \text {th part of something. Since the texts take care to differen- } \\
\text { tiate, two different translations should be used. }{ }^{40}\end{array}$ \\
\hline $\begin{array}{l}\text { mìnam ana d g̃ar } \\
\text { šà } A \text { inaddinam } Q \\
\text { ğar }\end{array}$ & $\begin{array}{l}\text { what to } d \text { shall I } \\
\text { posit that gives } \\
\text { me } A \text { ? Posit } Q\end{array}$ & $\begin{array}{l}\text { division question for numbers } d \text { which possess no ig i. } \\
\text { The expression is likely to refer to the way multipli- } \\
\text { cations were written on tablets for rough work }\end{array}$ \\
\hline
\end{tabular}

\section{Halves and bisection}

\begin{tabular}{||l|l|l||}
\hline mišlum/šu.ri.a & the half & $\begin{array}{l}\text { the half which belongs to the same category as the third } \\
\text { and the fourth }\end{array}$ \\
\hline
\end{tabular}

${ }^{38}$ The literal meaning of this Sumerian phrase is unclear. With $n=3,4$, and 5 it goes back at least to c. $2400 \mathrm{BCE}$, long before tables of reciprocals, which rules out the Old Babylonian folk etymology (given as an interlinear gloss) that igi $n$ should be what is written "facing" ( $p \bar{a} n \vec{\imath})$ the number $n$ in the table. The most likely interpretation was proposed by Jöran Friberg (neither he nor I remembered where last time I ask him) that it describes $n$ dots "placed" (gá 1 ) in "eye" (igi i), i.e., in circle - the protoliterate notation for fractions (in grain measure, $n=2,3,4$ and 5). Between evidence for one and the other notation there is a gap of some 500 years, from which, however, no notation for fractions has survived.

That the primary meaning of the term was connected to the table in the Old Babylonian period is clear from the name for technical constants: i g i.g u b, "fixed ig $\mathrm{i}$ ". These have nothing to do with reciprocals, but they are tabulated.

${ }^{39}$ It is the use of this verb that shows Assurbanipal to speak of reciprocals, not of division - cf. note 7 .

${ }^{40}$ Different texts use different stratagems to differentiate. The part may be expressed by the full phrase, and the reciprocal simply as ig i n; or the latter may be "detached", the former "torn out". What is shared by all texts is the effort to distinguish. 


\begin{tabular}{||l|l|l||}
\hline bāmtum ${ }^{41}$ & the moiety & $\begin{array}{l}\text { the "natural half" which could not be otherwise; as the } \\
\text { radius of the diameter. The non-technical meaning may } \\
\text { be, e.g., one of two rib-sides or one of two opposing } \\
\text { mountain slopes. }\end{array}$ \\
\hline muttatum & the half-part & $\begin{array}{l}\text { mathematical synonym of the preceding. Non-technical } \\
\text { meanings may refer to one of two opposing body parts, } \\
\text { to a donkey's half-pack, or to the literary formula "half } \\
\text { the kingdom" }\end{array}$ \\
\hline hepûm/gaz & to break & $\begin{array}{l}\text { the verb always going with the production of the natural } \\
\text { half. The non-general use is not restricted to bisection }\end{array}$ \\
\hline
\end{tabular}

\section{Standard names (for unknowns and other entities)}

\begin{tabular}{|c|c|c|}
\hline a. š à ${ }^{42}$ & surface & $\begin{array}{l}\text { the area of geometric figures (including the squares and } \\
\text { rectangles of the "algebra"), showing them to be formally } \\
\text { "fields". Problems pretending to deal with real fields } \\
\text { therefore have to refer to them in different words, even } \\
\text { though the basic meaning of eqlum/a.š à is precisely } \\
\text { "field" or "terrain". }\end{array}$ \\
\hline $\mathrm{us} \breve{s}^{3}$ & length & $\begin{array}{l}\text { the long side of a geometric figure (an "algebraic" rec- } \\
\text { tangle, but also a right triangle, etc.). A particular tradi- } \\
\text { tion of catalogue texts speak of the "length" of a square }\end{array}$ \\
\hline $\mathrm{sag}^{44}$ & width & $\begin{array}{l}\text { the short side of a geometric figure, in fixed couple with } \\
\text { the previous. Rarely used about the side of a square } \\
\text { (which is mostly a mithartum/"confrontation") }\end{array}$ \\
\hline šiddum/u š & flank / distance & $\begin{array}{l}\text { the long side of a real structure (a field, an irrigation } \\
\text { channel); or a distance (e.g., a carrying distance for } \\
\text { bricks) }\end{array}$ \\
\hline pūtum/s a g̃ & front & the short side of a real structure \\
\hline kīnum/gi.na & true & $\begin{array}{l}\text { used to distinguish between an original entity and a new } \\
\text { entity of the same kind (a length, a surface, etc.) })^{45}\end{array}$ \\
\hline sarrum/lu l & false & $\begin{array}{l}\text { as previous (but characterizes the new entity). The two } \\
\text { terms are never used together }\end{array}$ \\
\hline
\end{tabular}

${ }^{41}$ A small number of texts (mostly such as try to write everything except a few complements logographically) use the fraction sign transliterated $1 / 2 \log$ ographically or š u .ri . a . That a "natural half" is meant is then made clear by use of the verb "to break".

${ }^{42}$ In this function, the phonetic writing eqlum is never used; but a phonetic complement often shows that this pronunciation is intended.

${ }^{43}$ Except in a couple of very early texts from Eshnunna (see below), the corresponding phonetic writing šiddum is never used in this function; nor do phonetic complements indicate this (or any other) pronunciation.

${ }^{44}$ Except in a couple of very early texts from Eshnunna, the corresponding phonetic writing pūtum is never used in this function; not do phonetic complements indicate this pronunciation.

${ }^{45}$ The "true length" of a triangle may also be the length which comes closest to being perpendicular to the width. 


\begin{tabular}{|c|c|c|}
\hline šumma & if & $\begin{array}{l}\text { may serve to open the statement of a problem (as it } \\
\text { opens the protasis of an omen). In a sequence of analo- } \\
\text { gous procedures, it may also signal a variation within the } \\
\text { prescription ("if instead"); inside the prescription it may } \\
\text { also serve to introduce a smaller piece of deductive rea- } \\
\text { soning from already established foundations ("if [as you } \\
\text { have now established] ..."); finally, it may open a proof }\end{array}$ \\
\hline epēšum/kì d & $\begin{array}{l}\text { proceed/ } \\
\text { proceeding }\end{array}$ & $\begin{array}{l}\text { in the nominal sense, it may be used to open the pre- } \\
\text { scription with a phrase "you, by your proceeding" }\end{array}$ \\
\hline nēpešum & procedure & $\begin{array}{l}\text { mostly used to close the prescription (which then opens } \\
\text { simply "you"). In one text (Haddad 104) where variants } \\
\text { open šumma, the basic paradigm may start with nēpešum }\end{array}$ \\
\hline inūma & as & $\begin{array}{l}\text { used in a few texts inside the prescription to mark a } \\
\text { piece of deductive reasoning on already established foun- } \\
\text { dations }\end{array}$ \\
\hline aššum & since & $\begin{array}{l}\text { may serve as the preceding; may also be used to open } \\
\text { the prescription or to introduce a quotation from the } \\
\text { statement ("since, as it was said to you, ...") }\end{array}$ \\
\hline inanna & now & $\begin{array}{l}\text { may serve to separate general information in a statement } \\
\text { from the description of the actual situation }\end{array}$ \\
\hline sahāarum & to turn around & $\begin{array}{l}\text { marks subsections in the prescription; originally, it } \\
\text { seems, used to state that one has walked around a field } \\
\text { that was laid out, before giving other information }\end{array}$ \\
\hline târum & to turn back & similar to preceding (use as well as origin) \\
\hline $\begin{array}{l}-m a(\text { enclitic on } \\
\text { verb) }\end{array}$ & $:$ & $\begin{array}{l}\text { used to separate an operation from a numerical outcome } \\
\text { (in statement as well as prescription) }\end{array}$ \\
\hline kìma & as much as & $\begin{array}{l}\text { used in statements to indicate that the numerical out- } \\
\text { come of one operation equals that of another operation. } \\
\text { kima X may also stand for "as much as (there is of)" the } \\
\text { entity } X \text {, that is, its coefficient }\end{array}$ \\
\hline mala/a.na & so much as & $\begin{array}{l}\text { used as an "algebraic parenthesis" when complex quanti- } \\
\text { ties are constructed - "so much as } a \text { over } b \text { goes beyond" } \\
\text { meaning }(a-b)\end{array}$ \\
\hline kayamānum & always & $\begin{array}{l}\text { used (in one text, TMS XII, cf. [Muroi 2001]) to indicate } \\
\text { that a particular step is independent of the particular } \\
\text { numerical parameters of a problem }{ }^{46}\end{array}$ \\
\hline
\end{tabular}

\section{Asking}

\begin{tabular}{||l|l|l||}
\hline $\begin{array}{l}\text { minum } \\
\text { en.na m }{ }^{47}\end{array}$ & what & asks for the value of a quantity \\
\hline
\end{tabular}

\footnotetext{
${ }^{46}$ Of interest because the term turns up in Greek and Arabic in texts that ask for the "singling out" of magnitudes that are added in the statement (corresponding to Babylonian bêrum), cf. [Høyrup 1997: 92f].

${ }^{47} \mathrm{en} . \mathrm{nam}$ is a pseudo-Sumerogram apparently invented in the Old Babylonian period.
} 


\begin{tabular}{||l|l|l||}
\hline$k \bar{\imath}$ mași & $\begin{array}{l}\text { corresponding to } \\
\text { what }\end{array}$ & an alternative way to ask for the value of a quantity \\
\hline kiya & how much each & $\begin{array}{l}\text { used to ask for the values of each of several quantities } \\
\text { (in non-mathematical usage, no plurality seems to be } \\
\text { involved) }\end{array}$ \\
\hline
\end{tabular}

Recording, resulting

\begin{tabular}{|c|c|c|}
\hline 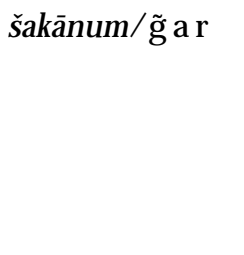 & to posit & $\begin{array}{l}\text { appears to designate various kinds of material record- } \\
\text { ing - "putting down" in a computational scheme, writing } \\
\text { a number onto a drawing, etc. Mainly used to take note } \\
\text { of data in the beginning of the prescription, and in the } \\
\text { formulation of the division problem "what may I posit } \\
\text {...", cf. above }{ }^{48}\end{array}$ \\
\hline lapātum & to inscribe & $\begin{array}{l}\text { to lay down in writing or drawing; some texts "inscribe" } \\
\text { "the equal" of a square and its "counterpart" }\end{array}$ \\
\hline nadûm & to lay down & $\begin{array}{l}\text { mathematical synonym of preceding - perhaps slightly } \\
\text { more tending toward drawing }\end{array}$ \\
\hline rēška likīl & $\begin{array}{l}\text { may your head } \\
\text { hold }\end{array}$ & $\begin{array}{l}\text { used for the recording in memory of intermediate results } \\
\text { that are not written down }\end{array}$ \\
\hline illiakkum & comes up for you & used in some texts to announce a numerical result \\
\hline tammar & you see & used in other texts for the same purpose ${ }^{49}$ \\
\hline nadānum/s u m & to give & $\begin{array}{l}\text { primarily used about numbers "given" by a table (of } \\
\text { reciprocals etc.); a few texts use it also about numerical } \\
\text { results "given" by an operation }\end{array}$ \\
\hline$-m a$ & $:$ & $\begin{array}{l}\text { the simplest way to announce the numerical result of an } \\
\text { operation (cf. above). Not rarely combined with } \\
\text { tammar }^{50}\end{array}$ \\
\hline
\end{tabular}

\section{The text groups}

Syllabic and logographic writings of the same operation may occur in the same text. Mathematical synonyms for subtraction by elimination also regularly (though not often) occur together within a text, depending on the particular situation and the general connotations of the term. With very rare exceptions, the other mathematical synonyms do not occur together, and the choice between such synonyms is indeed one of the parameters that allows us to distinguish between text groups within the Old Babylonian

\footnotetext{
${ }^{48}$ A single text (YBC 6504), also peculiar in other respects (e.g., using 1 b. $\mathrm{si}_{8}$ logographically for mithartum) "posits" (in. g a r) intermediate results

${ }^{49}$ A couple of late Old Babylonian texts use the logogram i g i. $\mathrm{d} \mathrm{u}_{8}$, whereas Old Akkadian school texts and 19th-c. texts from Ur use pàd .

${ }^{50}$ YBC 6504 also combines it with i n . g a r - cf. note 48. In the text material presented in [Høyrup 2002], one text $\left(\mathrm{Db}_{2}-146\right)$ further combines it with elûm, and one (YBC 4675) combines it once with nadānum and once with elûm. All of these are clearly rare exceptions.
} 
mathematical corpus.

As early as [1932: 6], Neugebauer suggested (from palaeography and certain terminological particularities) a division of the corpus into two main groups. His typical representatives for these groups (the Strasburg texts and BM 85194) can now be seen to come, respectively, from the core area of what had once been the Ur III state (probably Uruk, as indeed already suggested by Neugebauer) and from its northern periphery (Sippar). In 1945, Albrecht Goetze wrote a chapter for MCT, in which mainly orthographic (but to a limited extent also terminological) criteria led him to distinguish 6 distinct groups (thereby confirming and refining Neugebauer's hunches).

In 1996, as the work on translations had sharpened my attention to terminological shades, I took up the theme - adding two more groups which had been published in the meantime, the mathematical texts from Susa and those from Eshnunna, and in [Høyrup 2002] the 19th-c. texts from Ur and two texts from Nippur published by Eleanor Robson in [2000]. ${ }^{51}$ It turns out [Høyrup 2002: 319-358] that Goetze's groups correspond to outspoken terminological differences, and the split between the Ur-III core area and the periphery becomes more obvious than ever. Moreover, the beginnings of a history can now be outlined. In spite of what one might expect, the 19th-c. texts from Ur seem to represent a dead-end - later text groups from the core area do not share any of its terminological peculiarities (there are certain similarities with texts from the periphery, but none that suggest direct descent). Instead, the characteristic type of Old Babylonian mathematics appears to have two relatively independent starting points - in Eshnunna, in the north-east, in the decades beginning C. $1800 \mathrm{BCE}$, and in the south (Larsa?) around or somewhat before the mid-18th century. ${ }^{52}$

The terminological differences between text groups highlights one of the difficulties in the establishment of a set of "standard translations", as done above (some of the

\footnotetext{
${ }^{51}$ Misreading her paper, I also included CBS 43, CBS 154+921 and CBS 165 in this Nippur group. These texts are not from Nippur, and Eleanor Robson does not claim that they are. She tells me (personal communication) that they were purchased from a Baghdadi dealer in 1888. They might be from Sippar.

${ }^{52}$ Since the mathematical contents found in Eshnunna and the south is the same and both differ from the kind of mathematics we find in Old Babylonian Mari (north-west of Babylonia) in the early 18th c. or before [Soubeyran 1984], some inspiration is likely to have been present - perhaps after Hammurapi's conquest of Eshnunna in 1761 BCE?

Eleanor Robson [2001: 172] points out that the tablet Plimpton 322 (famous among mathematicians for its "Pythagorean triplets") shares the "landscape" format that was used in Larsa before this city fell to Hammurapi in 1762 bce. Since this format is anyhow the most fitting for the contents of the text (a table with many columns), and since teachers who had been accustomed to this format could well go on using it after the change of administrative regime when it was fitting, we have no reason to date the tablet to before 1762. On the other hand, the mathematical texts from the south are likely to antedate 1730 - statistics speaks against the ascription of a large number of undated texts to the period of the "Sealand" state, from which few dated documents are known.
} 
problems are pointed out in the list). How can we be sure that a particular term used in several text groups is meant to stand for the same entity or operation? One example, mentioned above, is the use of $1 \mathrm{~b} . \mathrm{si}_{8}$ as a logogram for mithartum in a restricted number of texts. Thureau-Dangin, in consequence, transcribed it consistently as mithartum in TMB, but careful analysis shows this to be a mistake; for the same reason, the word should not be translated in the same way in its two (or rather, three) functions. ${ }^{53}$

\section{Text format}

Mathematical texts are formulated in a particular terminology, and translation therefore involves decisions about how to render this. But whether formulated in words, diagrams, schemes and/or formulae, they are also arranged in a particular format. Changing this format entails loss of information about the thought of the author.

A typical line of an Old Babylonian mathematical text (BM 13901 \#12, obv. II, 29) runs like this:

ba-ma-at 21,40 te-he-pe-ma 10,50 ì 10,50 tu-uš-ta-kal

In what I have called the "conformal translation" this becomes: ${ }^{54}$

The moiety of 21'40" you break: 10'50" and 10'50" you make hold.

When quoting my translations in her recent book on Mathematics in Ancient Iraq, Eleanor Robson [2008: 277, 279] changes them so as to obtain "natural English word order". In the present case this would give

You break the moiety of 21'40": you make 10'50" and 10`50" hold.

The reason for this change is that Akkadian is verb-final and English not (to which comes the way English wraps composite verbal constructions around their object), and in so far is seems legitimate. However, we notice that the Akkadian line (and the conformal translation) have a particular "algorithmic structure" which takes advantage of the verb-final structure of the language:

number $_{1}$ operation $_{\mathrm{A}}$ : number $_{2}$ operation $_{\mathrm{B}}$

We see that a certain number (number ${ }_{1}$ ) is submitted to an operation (A). From this results a new number (number ${ }_{2}$ ), written after a -ma (translated ":"). This resulting number serves immediately without being repeated as the object of a new operation (B). In the "natural" translation we see instead that the result is not indicated as such.

\footnotetext{
${ }^{53}$ To make things worse, some groups write ba. $\mathrm{si}_{8}$, use "un-orthographic" (syllabo-phonetic) Sumerian (common in Eshnunna) i b . s i, or employ an Akkadian loan-word basûm. Only precise scrutiny of all occurrences in the single text groups allows us to decide whether the same translation is warranted.

${ }^{54}$ As usually, I employ Thureau-Dangin's transcription for sexagesimal place value numbers, ' indicating decreasing sexagesimal order of magnitude. 10`50" thus stands for $10 / 60+\frac{50}{3600}$.
} 
This chain-wise organization of the text cannot function everywhere. However, it is the predominant way of the mathematical authors to arrange their text (in linguists' terminology, the "unmarked" structure). Eliminating it from the translation makes the text less algorithmic and more discursive than it should be - and it makes us miss the rare and somehow significant occurrences of marked constructions. ${ }^{55}$

The Babylonian texts are also arranged in lines, very often (not consistently, lines may sometimes be to short to allow it) with line breaks that correspond to textual breaks. A faithful rendering of the texts should therefore also respect this arrangement.

Returning to the second initial observation, a translation which allows the reader to grasp how Old Babylonian mathematical thought differs from ours not only needs to be univocal; it also needs to establish the meaning of Babylonian mathematical terms not by simple de verbo ad verbum translation but explaining them "conceptual network to conceptual network" (as does the right column of the above tables). Moreover, it must reflect the discursive format of the original texts.

Even a direct reading of the Babylonian original texts (whether as written in clay or in transliteration) must understand their terminology in the same way, and take note of their organization.

\section{Translating abbacus mathematics}

"Abbacus mathematics" is the type of mathematics that was practised in the "abbacus school", the Italian ${ }^{56}$ school for artisans' and merchants' sons 11-12 years old, existing between 1260 and c. $1600 .^{57}$ The mathematical contents is close to what I was still taught in middle school in the 1950s (though at ages 13-14): rule of three, of partnership and of alligation; simple and composite interest; discounting; and such things. Some treatises introduce algebra (as I was introduced to it in the same years), even though this was not a topic of normal teaching but, as Pacioli [1494: $144^{\mathrm{r}}$ ] says, a pratica speculativa, a theoretical outgrowth of the practical-mathematical concerns.

Some years ago I undertook to translate Jacopo da Firenze's Tractatus algorismi, written in Montpellier in 1307 and the earliest extant Italian abbacus treatise containing

\footnotetext{
${ }^{55}$ Eleanor Robson's book has forced me to formulate this argument; in my [2002] it is not made explicit.

${ }^{56}$ More precisely, thriving between Genoa, Milan and Venice to the north and Tuscany and Umbria to the south.

${ }^{57}$ Traditionally, it has been claimed (without any serious argument having ever been given) to be inspired by or descend from Fibonacci's Liber abbaci (and, as far as its geometry is concerned, from his Pratica geometrie). In [Høyrup 2005] I explain why this cannot be true. Abbacus mathematics certainly has roots in a wider Mediterranean mathematical culture (as generally accepted), most directly in the Ibero-provençal area; the details of this are immaterial for the present discussion, as is the impact of the abbacus tradition on later practical arithmetic.
} 
an algebra (and plausibly the first to have been written). The two earliest abbacus treatises that we know about are from the years around 1290 (if not even later). Jacopo thus wrote at a moment when the terminology was still in flux, at least to the limited extent it was not determined by borrowings and loan translations from the IberoProvençal source tradition.

The linguistic closeness of Jacopo's text to the vernacular of his time; the simplicity of the Tuscan syntax of those contemporaries of Dante who did not share his ambition to emulate the artfulness of Latin when writing in volgare; and the substantial closeness to a mathematical tradition that was still quite alive in schools half a century ago (and which was an important ingredient in the shaping of the modern mathematical idiom) all of this contributed to making the translation task much easier than that of translating Old Babylonian mathematical texts. There was no Kuhnian divide between the conceptual worlds of abbacus and recent mathematics, and much less difference in language structure between Jacopo's text and English written at that simple level where English is a perfect global contact language (or "born pidgin").

Indeed, once I had decided upon a set of standard translations, much of my first rough translation of Jacopo's Tractatus could be made semi-automatically, as a controlled search-and-replace procedure (the varying spellings and grammatical declinations and conjugations of course excluded a fully automatic process). Translation of other texts from the time required slightly more circumspection - when a vocabulary is in flux, not everybody makes the same choices. On the whole, however, the method worked even for them. In the model of the initial translation from the Acts, the King James column was superfluous, and the "interlinear translation" could be arranged as naturally sounding English and at the same time as a literal translation.

So far, the situation was wholly different from the translation of Old Babylonian mathematics. However, if the translation is read as the secondary authors read those of Neugebauer and Thureau-Dangin, that is, through their further implicit or explicit translation into symbolic operations, similarities turn up, revealing conceptual incongruities that are easily overlooked. I shall discuss only two instances, but others could have been pointed out.

One has to do with geometry. A favourite configuration in abbacus geometry is the scudo or "shield", a triangle drawn in agreement with this designation as a $\nabla$ (and often with dimensions so large that a real shield cannot be meant). Mostly the shield is meant to be equilateral, and this is mostly taken to be so clear that it is not made further explicit. At times, however, it is stated explicitly. This could of course be done for pedagogical reasons - even if equilaterality is inherent in the concept, the reader might need to be taught. But occasionally we find "shields" which are only approximately equilateral. ${ }^{58} \mathrm{~A}$ "substantially adequate" translation as "equilateral triangle" would

\footnotetext{
${ }^{58}$ Thus Paolo Gherardi, ed. [Arrighi 1987: 71], a shield with sides 4, 6 and 8 palms - a slightly obtuse triangle.
} 
thus not fit everywhere, nor would however a translation "approximately equilateral triangle". The shield is "a triangle which is equilateral unless further information shows it not to be" - not exactly a concept we would expect to encounter in a contemporary mathematical text. ${ }^{59}$

The other concerns division. Division may be partire in and partire per, respectively "divide in" and "divide by". It is easy to overlook the difference and translate both as "divide by". At closer inspection of Jacopo's text, however, it turns out that every time division is made by a number which has been stated to be the partitore ("divisor"), division is in; in particular, this holds for all proportional partitions (that is, in applications of the partnership rule). On the other hand, when a circular diameter is found from the perimeter, it is always through division per $3 \frac{1}{7}$.

Obviously, the idea behind division in $n$ is the division into $n$ parts, whereas division per refers to the numerical operation. This, however, is not clear to Jacopo; time and again he divides per so and so many parts. Nor was it clear to his fellowItalians; as time passed, division per ended up dominating even where early texts had divided in. When we look at Italian texts alone, there is thus no conceptual distinction between the two different expressions, only an ill-understood and gradually fading habit. If we look instead at Iberian writings, we see that the difference was still conceptual in Catalonia as late as 1482 (Francesc Santcliment, ed. [Malet 1998]). The distinction is thus a trace of historical diffusion - and the fact that normalization of two-term algebraic equations is a division per while three-term equations are normalized through division in [Høyrup 2007: 177] could probably tell us something about the immediate prehistory of Jacopo's algebra - if only we had possessed the adequate material from the Ibero-Provençal world, which is not the case.

Even when we examine a mathematical type so close to our own as abbacus mathematics, close attention to words is thus needed if we want to be sure to understand its concepts and if we want to trace historical trends.

\section{A concluding remark}

What was said in the preceding two sections about how translations "should" be made was not meant as an general imperative. They stated what must be done if one is the overcome the "Kuhnian divide" between our present mathematical thought and that of a past culture - and therefore they do not concern the problem of translation alone but also a dictionary-based understanding of the ancient texts themselves. In any case, translations of this kind are meant, in the introductory simile, for the "preachers and teachers" of the history of mathematical thought rather than for the lay users of the history of mathematics.

Translations are indeed always mediators between a foreign text and a particular

\footnotetext{
${ }^{59}$ On the other hand, it might fit into Lakatos" "logic of mathematical discovery" [1976].
} 
present perspective (Peirce's "perspective from nowhere" is a philosophers' pipe dream); it cannot serve all perspectives, it must forsake rendering certain aspects if it is to represent others adequately. Rendering a sonnet as a sonnet implies that the words must be treated rather freely; translating the words precisely implies a translation into prose or very clumsy verse. And: When writing the economic history of Ur III it is quite fitting to express the quantity of cloth woven in Ur in a particular year in modern metrology; if one wants to illustrate the history of accounting, the texts have to be rendered with the metrology they used - and if the history of tabular formats is in focus, the organization of texts on tablets must be conserved in translation.

Similarly when mathematical texts are transposed and interpreted. Referring to a paradigmatic discussion we may say that the questions asked by Sabetai Unguru in [1975] were fully legitimate, and that they had to do with overcoming the Kuhnian divide which separates us from the Greek geometers. But the questions addressed by André Weil [1978] were also legitimate, and beyond the desire of the present-day mathematician to recognize his own activity in the past they had to do with a very deep and intricate question pertaining to the philosophy of mathematics ${ }^{60}$ - namely that Eugene Wigner's renowned "unreasonable effectiveness of mathematics" [1960] does not respect the limits between incompatible conceptual worlds (for which reason there must be some connection between the theorems of Elements II and those of modern algebra). The effort of both to deny the other part the right to ask their questions, on the other hand, is hardly legitimate.

As philosophers are turning away from the "linguistic turn", having learned as much from it as they could, historians of scientific knowledge should perhaps recognize that the corresponding approach to their own field does not lead to the only truth worth knowing. Discussions of discordant conceptual worlds and the difficulties they create for translators have to be combined, inter alia and to the extent it can be done, with understanding of the practice of the ancient scholars ${ }^{61}$ and related to the objects they were knowing about.

\section{References}

Arrighi, Gino (ed.), 1987. Paolo Gherardi, Opera mathematica: Libro di ragioni - Liber habaci. Codici Magliabechiani Classe XI, nn. 87 e 88 (sec. XIV) della Biblioteca Nazionale di Firenze. Lucca: Pacini-Fazzi. Berry, George Ricker, 1897. I. The Interlinear Literal Translation of the Greek New Testament. II.Greek-English Lexicon to the New Testament. Reading, Pennsylvania: Handy Book Company, 1897.

Bezold, Carl, 1926. Babylonisch-Assyrisches Glossar. Heidelberg: Carl Winter, 1926.

\footnotetext{
${ }^{60}$ Within the horizon of each combatant one might certainly claim that the answers they give are partially mistaken, but that is not the point here. Nor are the nasty ways in which both attacks are formulated, worthy of a Luther or a Paracelsus.

${ }^{61}$ Inasfar as Old Babylonian mathematics is concerned we may still complain with Neugebauer that we know next to nothing beyond plausible conjectures based on indirect arguments!
} 
Borger, Rykle, 2004. Mesopotamisches Zeichenlexikon. (AOAT, 305). Münster: Ugarit-Verlag.

Castellino, G. R., 1972. Two Šulgi Hymns (BC). (Studi semitici, 42). Roma: Istituto di studi del Vicino Oriente.

Frank, Carl, 1928. Straßburger Keilschrifttexte in sumerischer und babylonischer Sprache. (Schriften der Straßburger

Wissenschaftlichen Gesellschaft in Heidelberg, Neue Folge, Heft 9). Berlin \& Leipzig: Walter de Gruyter.

Friberg, Jöran, 2000. "Mathematics at Ur in the Old Babylonian Period". Revue d'Assyriologie et d'Archéologie Orientale 94, 97-188.

Gardiner, Alan H., 1911. Egyptian Hieratic Texts. Series I: Literary Texts from the New Kingdom. Part I: The Papyrus Anastasi I and the Papyrus Koller, together with Parallel Texts. Leipzig: J. C. Hinrichs'sche Buchhandlung.

Goetsch, H., 1968. "Die Algebra der Babylonier". Archive for History of Exact Sciences 5 (1968-69), 79-153.

Grant, Hardy, 2009. [Essay review af Giora Hon \& Bernard Goldstein, From Summetria to Symmetry: The Making of a Revolutionary Scientific Concept. New York: Springer, 2008]. Historia Mathematica 36, 171-177.

Gundlach, Karl-Bernhard, \& Wolfram von Soden, 1963. "Einige altbabylonische Texte zur Lösung "quadratischer Gleichungen«". Abhandlungen aus dem mathematischen Seminar der Universität Hamburg 26, 248-263.

Høyrup, Jens, 1995. "Linee larghe. Un'ambiguità geometrica dimenticata”. Bollettino di Storia delle Scienze Matematiche 15, 3-14.

Høyrup, Jens, 1997. “Hero, Ps.-Hero, and Near Eastern Practical Geometry. An Investigation of Metrica, Geometrica, and other Treatises", pp. 67-93 in Klaus Döring, Bernhard Herzhoff \& Georg Wöhrle (eds), Antike Naturwissenschaft und ihre Rezeption, Band 7. Trier: Wissenschaftlicher Verlag Trier.

Høyrup, Jens, 2000. Human Sciences: Reappraising the Humanities through History and Philosophy. Albany, New York: State University of New York Press.

Høyrup, Jens, 2002. Lengths, Widths, Surfaces: A Portrait of Old Babylonian Algebra and Its Kin. (Studies and Sources in the History of Mathematics and Physical Sciences). New York: Springer, 2002.

Høyrup, Jens, 2005. “Leonardo Fibonacci and Abbaco Culture: a Proposal to Invert the Roles". Revue d'Histoire des Mathématiques 11, 23-56.

Høyrup, Jens, 2007. Jacopo da Firenze's Tractatus Algorismi and Early Italian Abbacus Culture. (Science Networks. Historical Studies, 34). Basel etc.: Birkhäuser.

Kuhn, Thomas S., 1970. The Structure of Scientific Revolutions. (International Encyclopedia of Unified Science, Vol. 2, No 2). ${ }^{2}$ Chicago: University of Chicago Press.

Lakatos, Imre, 1976. Proofs and Refutations: The Logic of Mathematical Discovery. Cambridge: Cambridge University Press.

Malet, Antoni (ed.), 1998. Francesc Santcliment, Summa de l'art d'Aritmètica. Vic: Eumo Editorial.

MCT: Otto Neugebauer \& Abraham Sachs, Mathematical Cuneiform Texts. (American Oriental Series, vol. 29). New Haven, Connecticut: American Oriental Society, 1945.

MKT: Otto Neugebauer, Mathematische Keilschrift-Texte. I-III. (Quellen und Studien zur Geschichte der Mathematik, Astronomie und Physik. Abteilung A: Quellen. 3. Band, erster-dritter Teil). Berlin: Julius Springer, 1935, 1935, 1937.

Muroi, Kazuo, 2001. "Reexamination of the Susa Mathematical Text No. 12: A System of Quartic Equations". SCIAMUS 2, 3-8.

Neugebauer, Otto, 1929. "Zur Geschichte der babylonischen Mathematik". Quellen und Studien zur Geschichte der Mathematik, Astronomie und Physik. Abteilung B: Studien 1, 67-80.

Neugebauer, Otto, 1932. "Studien zur Geschichte der antiken Algebra I". Quellen und Studien zur Geschichte der Mathematik, Astronomie und Physik. Abteilung B: Studien 2, 1-27.

Neugebauer, Otto, 1934. Vorlesungen über Geschichte der antiken mathematischen Wissenschaften. I: Vorgriechische Mathematik. (Die Grundlehren der mathematischen Wissenschaften in Einzeldarstellungen, Bd. XLIII). Berlin: Julius Springer.

Pacioli, Luca, 1494. Summa de Arithmetica Geometria Proportioni et Proportionalita. Venezia: Paganino de Paganini.

Robson, Eleanor, 2000. "Mathematical Cuneiform Tablets in Philadelphia. Part 1: Problems and Calculations". SCIAMUS 1, 11-48. 
Robson, Eleanor, 2001. “Neither Sherlock Holmes nor Babylon: a Reassessment of Plimpton 322". Historia Mathematica 28, 167-206.

Robson, Eleanor, 2008. Mathematics in Ancient Iraq: A Social History. Princeton \& Oxford: Princeton University Press.

Schuster, H. S., 1930. "Quadratische Gleichungen der Seleukidenzeit aus Uruk". Quellen und Studien zur Geschichte der Mathematik, Astronomie und Physik. Abteilung B: Studien 1, 194-200.

Soubeyran, Denis, 1984. “Textes mathématiques de Mari”. Revue d'Assyriologie 78, $19-48$.

Thureau-Dangin, François, 1922. Tablettes d'Uruk. Paris: Musée du Louvre. Not seen on the present occasion.

Thureau-Dangin, François, 1940. "L'Origine de l'algèbre". Académie des Belles-Lettres. Comptes Rendus 1940, 292-319.

TMB: François Thureau-Dangin, Textes mathématiques babyloniens. (Ex Oriente Lux, Deel 1). Leiden: Brill.

Unguru, Sabetai, 1975. "On the Need to Rewrite the History of Greek Mathematics". Archive for History of Exact Sciences 15, 67-114.

Vajman, Aisik A., 1961. Šumero-vavilonskaja matematika. III-I Tysjačeletija do n. e. Moskva: Izdatel'stvo Vostočnoj Literatury.

van der Waerden, Bartel Leendert, 1956. Erwachende Wissenschaft. Ägyptische, babylonische und Griechische Mathematik. Basel \& Stuttgart: Birkhäuser.

Vogel, Kurt, 1959. Vorgriechische Mathematik. II. Die Mathematik der Babylonier. (Mathematische Studienhefte, 2). Hannover: Hermann Schroedel / Paderborn: Ferdinand Schöningh.

von Soden, Wolfram, 1939. [Review of TMB]. Zeitschrift der Deutschen Morgenländischen Gesellschaft 93, 143-152.

von Soden, Wolfram, 1974. Sprache, Denken und Begriffsbildung im Alten Orient. (Akademie der Wissenschaften und der Literatur. Abhandlungen der Geistes- und Sozialwissenschaftlichen Klasse, 1973 Nr. 6). Mainz: Akademie der Wissenschaften und der Literatur / Wiesbaden: Franz Steiner.

Weil, André, 1978. "Who Betrayed Euclid?" Archive for History of Exact Sciences 19, 91-93.

Wigner, Eugene, 1960. "The Unreasonable Effectiveness of Mathematics in the Natural Sciences". Communications in Pure and Applied Mathematics 13:1, 1-14. 